\title{
IMPLEMENTASI SISTEM PENGENDALIAN INTERN PEMBERIAN KREDIT PADA PT. BANK PERKREDITAN RAKYAT (BPR) PHIDECTAMA BIAK
}

\author{
VICTOR F. F. D. PASALBESSY, SE., ME \\ Dosen Prodi Ekonomi Pembangunan, STIE Port Numbay Jayapura
}

\begin{abstract}
This study aims to determine the procedure for granting credit at PT. Rural Bank (BPR) Phidectama Biak; To find out the implementation of the internal control system for providing credit at PT. Rural Bank (BPR) Phidectama Biak in accordance with the elements of internal control according to COSO; and to find out the factors that hinder the implementation of the internal control system in providing credit at PT. People's Credit Bank (BPR) Phidectama Biak. The results of the study prove that the procedure for granting credit at PT. The Rural Bank (BPR) Phidectama Biak has complied with the provisions of the procedures it has, although in practice there are still deviations made. Procedure for granting credit at PT. Rural Bank (BPR) Phidectama Biak, among others: credit applications, customer review analysis, analysis of customer review reports, credit decisions, approval of credit applications and credit disbursement; Implementation of the internal control system for granting credit at PT. The Rural Bank (BPR) Phidectama Biak is mostly in the components of the control environment, risk assessment, information and communication, monitoring is in accordance with the internal control component according to COSO. The factors that hinder the implementation of the internal control system in providing credit at PT. Rural Bank (BPR) Phidectama Biak, among others: the proximity of employees to prospective customers, incomplete requirements in submitting credit applications, and false information provided by prospective customers.
\end{abstract}

Keywords: Internal Control System, Credit Provision

\begin{abstract}
Abstrak: Penelitian ini bertujuan untuk mengetahui prosedur pemberian kredit pada PT. Bank Perkreditan Rakyat (BPR) Phidectama Biak; Untuk mengetahui implementasi sistem pengendalian intern pemberian kredit yang terdapat pada PT. Bank Perkreditan Rakyat (BPR) Phidectama Biak sesuai dengan unsur pengendalian intern menurut COSO; dan Untuk mengetahui faktor-faktor yang menghambat implementasi sistem pengendalian intern pemberian kredit pada PT. Bank Perkreditan Rakyat (BPR) Phidectama Biak. Hasil penelitian membuktikan bahwa Prosedur pemberian kredit pada PT. Bank Perkreditan Rakyat (BPR) Phidectama Biak sudah sesuai dengan ketentuan prosedur yang dimiliki, walaupun dalam prakteknya masih terdapat penyimpangan-penyimpangan yang dilakukan. Prosedur pemberian kredit di PT. Bank Perkreditan Rakyat (BPR) Phidectama Biak antara lain : permohonan kredit, analisis peninjauan nasabah, analisis laporan hasil peninjauan nasabah, keputusan kredit, persetujuan permohonan kredit dan pencairan kredit; Implementasi sistem pengendalian intern pemberian kredit pada PT. Bank Perkreditan Rakyat (BPR) Phidectama Biak sebagian besar dalam komponen lingkungan pengendalian, penilaian risiko, informasi dan komunikasi, pemantauan sudah sesuai dengan komponen pengendalian intern menurut COSO. Faktor-faktor yang menghambat implementasi sistem pengendalian intern pemberian kredit pada PT. Bank Perkreditan Rakyat (BPR) Phidectama Biak antara lain : faktor kedekatan pegawai dengan calon nasabah, Persyaratan tidak lengkap dalam pengajuan permohonan kredit, dan informasi palsu yang diberikan oleh calon nasabah.
\end{abstract}

Kata Kunci : Sistem Pengendalian Intern, Pemberian Kredit

\section{Latar Belakang}

Bank mempunyai peranan yang sangat penting dalam perekonomian di Indonesia untuk berbagai kegiatan yang berkaitan dengan keuangan. Bank adalah suatu lembaga yang berperan sebagai perantara keuangan (financial intermediary) antara pihak-pihak yang memiliki kelebihan dana (surplus unit) dengan pihak-pihak yang memerlukan dana (deficit unit), serta sebagai lembaga yang berfungsi memperlancar lalu lintas pembayaran. Falsafah yang mendasari kegiatan usaha bank adalah kepercayaan masyarakat. Hal ini tampak dari kegiatan pokok bank yang menerima simpanan dari masyarakat yang kelebihan dana dalam bentuk giro, tabungan serta deposito berjangka dan memberikan kredit kepada pihak yang memerlukan dana (Ikatan Bankir Indonesia, 1999).

Bank merupakan suatu lembaga perantara keuangan yang memberikan jasa-jasa keuangan baik berupa tabungan maupun pinjaman. Menurut Undang-Undang No. 10 Tahun 1998 tentang Perbankan, pengertian bank adalah badan usaha yang menghimpun dana dari masyarakat dalam
On Assets.

bentuk simpanan dan menyalurkannya kepada masyarakat dalam bentuk kredit dan atau bentuk-bentuk lainnya dalam rangka meningkatkan taraf hidup rakyat banyak.

Dalam Undang - Undang No. 10 Tahun 1998 tentang Perbankan bahwa bank ada dua jenis bank yaitu Bank Umum dan Bank Perkreditan Rakyat. Bank secara umum memiliki kegiatan pokok antara lain meghimpun dana dari masyarakat dalam bentuk simpanan berupa giro, deposito berjangka, tabungan, dan atau bentuk lainnya, memberikan kredit, menerbitkan surat pengakuan utang, menyediakan tempat untuk menyimpan barang dan surat berharga. Bank Perkreditan Rakyat memiliki kegiatan yang jauh lebih sempit dibandingkan dengan kegiatan bank umum karena Bank Perkreditan Rakyat memiliki kegiatan usaha antara lain memberikan kredit, menempatkan dananya dalam bentuk Sertifikat Bank Indoensia (SBI), deposito berjangka, sertifikat deposito, dan tabungan pada bank lain. Selain itu, Bank Perkreditan Rakyat juga melakukan kegiatan menghimpun dana dari masyarakat 
dalam bentuk simpanan berupa deposito berjangka, tabungan, dan atau bentuk lainnya yang dipersamakan dengan itu.

Kredit berasal dari bahasa Italia, yaitu credare yang berarti kepercayaan. Makna dari kata kredit menunjukkan kegiatan pemberian kredit didasari oleh kepercayaan. Kepercayaan ini berarti bahwa pihak yang memberikan pinjaman (kreditor) percaya bahwa penerima pinjaman (debitur) akan mengembalikan pinjaman beserta bunganya sesuai dengan perjanjian kedua belah pihak.

Kredit adalah kegiatan operasional terpenting dalam kegiatan operasi bank, karena kredit memiliki nilai aset terbesar jika dibandingkan dengan kegiatan operasional bank lainnya. Memang sepantasnya bila bank memberikan perhatian yang lebih kepada kegiatan perkreditan dengan melakukan pengawasan pada bidang perkreditan tersebut.

Bank memberikan kreditnya berdasarkan kepercayaan kepada debitur, walaupun pemberian kredit didasarkan pada kepercayaan, penilaian atas kepercayaan juga harus didasari oleh kriteria penilaian kredit yang harus dilakukan oleh bank untuk mendapatkan nasabah yang benar-benar menguntungkan dilakukan dengan mengunakan analisis 5C dan 7P. Kredit dengan penilaian 5C berisi penilaian tentang character, capacity, capital, condition, dan collateral, sedangkan penilaian kredit dengan analisis 7P berisi penilaian tentang personality, party, purpose, prospect, payment, profitability, dan protection. Penilaian kredit tersebut berguna untuk meminimalisasi risiko kredit pada debitur seperti kredit macet.

Pemberian kredit merupakan kegiatan yang mengandung risiko yang dapat berpengaruh pada kesehatan dan kelangsungan usaha perusahaan sehingga membutuhkan pengendalian. Untuk mendukung terciptanya pemberian kredit yang sehat, bank harus benar-benar memperhatikan pengendalian intern sudah dipatuhi selama proses pemberian kredit. Hal ini dilakukan untuk mencegah terjadinya resiko kredit yang telah diberikan kepada debitur mengalami kemacetan. Jika kredit bermasalah ini tidak ditangani dengan baik maka kredit bermasalah ini dapat menganggu kelancaran usaha bank yang tentunya dapat menimbulkan krisis kepercayaan dari masyarakat. Oleh karena itu, sistem pemberian kredit yang diterapkan oleh pihak bank akan lebih efektif apabila di dalam bank tersebut terdapat pengendalian intern yang kuat sebagai dasar kegiatan operasional bank yang sehat dan aman dalam manajemen bank.

Pengertian pengendalian intern menurut AICPA (American Institute of Certified Public Accountants) meliputi struktur organisasi, semua metode dan ketentuanketentuan yang terkoordinasi yang dianut dalam perusahaan untuk melindungi harta kekayaan, memeriksa ketelitian, dan seberapa jauh data akuntansi dapat dipercaya meningkatkan efisiensi usaha dan mendorong ditaatinya kebijakan perusahaan yang telah diterapkan.Tujuan pengendalian intern adalah untuk memberikan keyakinan memadai dalam pencapaian tiga golongan tujuan yaitu: (1) keandalan informasi keuangan, (2) kepatuhan terhadap hukum dan peraturan yang berlaku, (3) efektifitas dan efisiensi operasi.

Dalam penyaluran kredit diperlukan adanya pengendalian intern agar terhindar dari segala bentuk resiko dan penyelewengan yang mungkin terjadi. Sistem pengendalian intern tersebut dapat dibagi menjadi dua macam yaitu pengendalian intern akuntansi (internal accounting control) dan pengendalian intern administratif (internal administrative control). Pengendalian intern akuntansi yang merupakan bagian dari sistem pengendalian intern meliputi struktur organisasi, metode dan ukuranukuran yang dikoordinasikan terutama untuk menjaga kekayaan organisasi dan mengecek ketelitian dan keandalan data akuntansi. Pengendalian intern akuntansi yang baik akan menjamin keamanan kekayaan para investor dan kreditur yang ditanamkan dalam perusahaan dan akan menghasilkan laporan keuangan yang dapat dipercaya. Pengendalian intern administratif meliputi struktur organisasi, metode dan ukuran-ukuran yang dikoordinasikan terutama untuk mendorong efisiensi dan dipatuhinya kebijakan manajemen (Mulyadi, 2001).

Bank perlu melakukan tinjauan serta melaksanakan pengendalian intern kredit yang mencakup semua aspek dalam pemberian kredit yang akan mempengaruhi kelangsungan hidup bank sehingga dapat dipastikan bahwa pemberian kredit yang dilakukan oleh bank sesuai dengan aturan yang berlaku.

PT. Bank Perkreditan Rakyat (BPR) Phidectama Biak adalah bank yang menjadikan kredit sebagai produk utama selain tabungan. Oleh sebab itu, dengan adanya implementasi pengendalian intern dan prosedur pemberian kredit yang diterapkan dengan baik, maka manajemen dapat menjaga aset perusahaan, sebaliknya bila tdk diterapkan dengan baik pengendalian internnya maka di masa mendatang bank akan mengalami wanprestasi, dimana bank sulit mendapatkan keuntungan melainkan akan menimbulkan kredit bermasalah. Dan kalau sudah sampai pada kredit bermasalah, maka kemungkinan besar tidak ada keuntungan atau deviden yang diperoleh, maka akan terjadi masalah likuiditas bank dan bank terancam ditutup.

Oleh sebab itu, salah satu fungsi bank sebagai penyalur atau pemberi kredit, tentunya dalam pelaksanaan fungsi ini diharapkan bank mendapatkan sumber pendapatan berupa bagi hasil atau dalam bentuk pengenaan bunga kredit. Pemberian kredit akan menimbulkan resiko, oleh sebab itu pemberiannya harus benar-benar teliti dan memenuhi persyaratan. Apabila kredit bermasalah dibiarkan begitu saja, maka dapat menyebabkan kerugian materi bagi bank karena selain mengganggu aktivitas bank juga dapat merusak nama baik bank. Kita pernah mendengar beberapa bank dilikuidasi atau dibekukan usahanya, salah satu penyebabnya adalah karena banyak kredit yang bermasalah atau macet. Pentingnya sistem pengendalian intern terhadap pemberian kredit untuk menekan terjadinya kredit bermasalah maka penulis tertarik untuk mengadakan penelitian mengenai "Implementasi Sistem Pengendalian Intern Pemberian Kredit Pada PT. BPR. Phidectama Biak". 


\section{Perumusan Masalah}

Berdasarkan dari uraian yang ada di latar belakang masalah, maka perumusan masalahnya adalah:

1. Bagaimana prosedur pemberian kredit pada PT. Bank Perkreditan Rakyat (BPR) Phidectama Biak?

2. Apakah implementasi sistem pengendalian intern pemberian kredit yang terdapat pada PT. Bank Perkreditan Rakyat (BPR) Phidectama Biak sesuai dengan unsur pengendalian intern menurut COSO?

3. Faktor-faktor apa yang menghambat implementasi sistem pengendalian intern pemberian kredit pada PT. Bank Perkreditan Rakyat (BPR) Phidectama Biak?

\section{Tujuan Penelitian}

Perumusan masalah yang telah diuraikan pada bagian sebelumnya dapat digunakan untuk menentukan tujuan dari penelitian ini. Tujuan dari penelitian ini yaitu:

1. Untuk mengetahui prosedur pemberian kredit pada PT. Bank Perkreditan Rakyat (BPR) Phidectama Biak;

2. Untuk mengetahui implementasi sistem pengendalian intern pemberian kredit yang terdapat pada PT. Bank Perkreditan Rakyat (BPR) Phidectama Biak sesuai dengan unsur pengendalian intern menurut COSO;

3. Untuk mengetahui faktor-faktor yang menghambat implementasi sistem pengendalian intern pemberian kredit pada PT. Bank Perkreditan Rakyat (BPR) Phidectama Biak.

\section{Lokasi Penelitian}

Berdasarkan judul yang dipilih oleh penulis dalam penelitian ini, maka yang menjadi objek penelitian adalah PT. Bank Perkreditan Rakyat (BPR) Phidectama Biak dengan alamat Jalan Bosnik Raya, Karang Mulia, Samofa, Kabupaten Biak Numfor, Papua. Kode Pos 98111, Telp. (0981) 26108

\section{Landasan Teori}

\section{Pengertian Sistem Pengendalian Intern}

Sebelumnya istilah yang dipakai untuk pengendalian intern adalah sistem pengendalian intern, sistem pengawasan intern dan struktur pengendalian intern, mulai tahun 2011 istilah resmi yang digunakan IAI adalah pengendalian intern, hal ini dikemukakan oleh Setyowati, Agatha Gerry, (2007)

Menurut Setyowati, Agatha Gerry, (2007) Pengendalian intern dapat mempunyai arti yang sempit atau juga luas. Dalam arti yang sempit, pengendalian intern merupakan pengecekan penjumlahan, baik penjumlahan mendatar maupun penjumlahan menurun. Dalam arti yang luas pengendalian intern tidak hanya meliputi pekerjaan pengecekan, tetapi meliputi semua alat-alat yang digunakan manajemen untuk mengadakan pengawasan. Adapun juga beberapa definisi terhadap pengendalian intern yang dikemukakan oleh para ahli.

Menurut Mulyadi (2002: 163), sistem pengendalian intern didefinisikan sebagai berikut: "Sistem pengendalian intern meliputi struktur organisasi, metode dan ukuran-ukuran yang dikoordinasikan untuk menjaga kekayaan organisasi, mengecek ketelitian dan keandalan data akuntansi, mendorong efisiensi dan mendorong terjadinya kebijakan manajemen. Definisi sistem pengendalian intern tersebut menekankan tujuan yang hendak dicapai, dan bukan pada unsur-unsur yang membentuk sistem tersebut, dengan demikian pengertian pengendalian intern tersebut diatas berlaku baik dalam perusahaan yang engolah informasinya secara manual, dengan mesin pembukuan, maupun dengan komputer."

Sedangkan menurut Romney dan Steibart (2006) mendefinisikan sebagai berikut : pengendalian internal adalah suatu proses karena termasuk didalam aktivitas operasional organisasi dan merupakan bagian integral dari kegiatan pengelolaan. pengendalian internal memberikan jaminan yang lengkap dan wajar untuk sulit dicapai. Selain sistem pengendalian intern memiliki keterbatasan, seperti kerentanan terhadap kesalahan sederhana, penilaian yang salah dan pengambilan keputusan, mengabaikan manajemen dan terjadinya kolusi.

Menurut Setyowati, Agatha Gerry, (2007)Pengendalian internal adalah proses yang dipengaruhi oleh dewan entitas direksi, dan personil lainnya, yang dirancang untuk memberikan keyakinan tentang pencapaian tujuan dalam kategori berikut: a). Keandalan pelaporan keuangan; b). Kepatuhan terhadap hukum dan peraturan yang berlaku; dan c). Efektivitas dan efisiensi operasi

Berdasarkan definisi-definisi diatas menurut pakar akuntansi, disini dapat kita tarik kesimpulan bahwa tujuan dari sistem pengendalian intern adalah : 1). Pengamanan atas harta milik perusahaan; 2). Menciptakan data akuntansi yang akurat / tepat; 3). Peningkatan efisiensi operasional (biaya, waktu, beban); dan 4). Mendorong dipatuhinya atau ditaatinya kebijakan-kebijakan manajemen.

Sistem pengendalian intern yang baik harus mempunyai struktur pengendalian intern yang baik pula, yaitu harus mempunyai prosedur dan tujuan yang jelas. Tujuan yang jelas disini dimaksudkan bahwa struktur pengendalian intern suatu perusahaan terdiri dari kebijakan-kebijakan dan prosedur-prosedur yang ditetapkan untuk memberikan cukup kepastian akan sasaran dan tujuan perusahaan yang akan dicapai.

\section{Unsur Sistem Pengendalian Intern}

Menurut Setyowati, Agatha Gerry, (2007) dapat disimpulakan untuk memberikan struktur untuk mempertimbangkan banyak kontrol mungkin terkait dengan pencapaian tujuan entitas, laporan COSO mengidentifikasi lima komponen yang saling terkait dalam pengendalian internal:

1. Control environment, menetapkan tujuan dari sebuah organisasi, yang mempengaruhi kesadaran pengendalian orang-orangnya. Ini adalah dasar untuk semua komponen lain dari pengendalian intern, menyediakan disiplin dan struktur. Control environment yang kuat terdiri dari berbagai faktor yang bekerja sama untuk meningkatkan kesadaran pengendalian orang-orang yang menerapkan kontrol bagi seluruh entitas. Faktorfaktor tersebut antara lain:

a. Integrity and ethical values 
Laporan COSO mencatat bahwa manajer entitas dikelola dengan baik telah semakin diterima pandangan bahwa "etika bayar bahwa perilaku etis adalah bisnis yang baik". dalam rangka untuk menekankan pentingnya integritas dan etika nilainilai di antara semua personil organisasi, CEO dan anggota lain dari top management.

b. Commitment to competence

Kompetensi seharusnya berhubungan terhadap pengetahuan dan keahlian yang diperlukan untuk memenuhi tugas yang terdapat dalam suatu perkerjaan. Komitment terhadap kompetensi termasuk juga pertimbangan manajement terhadap tingkat kompetensi tertentu atas suatu pekerjaan dan bagaimana tingkatan tersebut menerjemahkan kedalam persyaratan keahlian dan pengetahuan

c. Board of directors and audit committee

Susunan dewan direksi dan komite audit dan cara di mana mereka menjalankan tanggung jawab pemerintahan dan pengawasan mereka memiliki dampak yang besar pada lingkungan pengendalian. faktor yang mempengaruhi efektivitas dewan dan komite audit meliputi kemerdekaan mereka yang diperoleh dari manajemen.

d. Management's philosophy and operating style

Karakteristik dapat membentuk bagian dari filsafat dan gaya operasi manajemen dan berdampak pada lingkungan pengendalian. Karakteristik tersebut yaitu mengawasi resiko bisnis, perilaku dan tindakan terhadap laporan keuangan, pemilihan terhadap prinsip akuntansi yang ada, mengerti resiko yang terkait dengan IT.

e. Organizational structure

Struktur organisasi dalam suatu organisasi perusahaan bertujuan menyediakan kerangka kerja untuk aktivitas dalam mencapai tujuan dengan perencanaan, pelaksanaan, pengendalian dan pengawasan. Hal yang cukup signifikan dalam struktur organisasi adalah area kunci atas wewenang ,tanggung jawab dan ketepatan pelaporan.

f. Assigment of authority and responsibility

Tugas wewenang dan tanggung jawab meliputi keterangan tentang bagaimana dan kepada siapa wewenang dan tanggung jawab untuk semua kegiatan entitas ditanda tangani, dan harus memungkinkan setiap individu untuk mengetahui bagaimana tindakannya saling berhubungan dengan orang lain untuk berkontribusi dalam pencapaian tujuan entitas dan untuk apa diadakan tanggung jawab bagi setiap individu.

g. Human resources policies and practices.

Kebijakan dan praktek dalam pengelolaan sumber daya manusia berpengaruh terhadap ketercukupan tenaga kerja dalam mencapai tujuan yang ingin dicapai oleh suatu perusahaan. Kebijakan dan praktek sumber daya manusia ini seperti kebijakan perusahaan dalam prosedur perekrutan, program magang, pelatihan, evaluasi, counseling, promosi, kompensasi dan tindakan perbaikan. Di beberapa perusahaan, kebijakan yang diterapkan bisa saja tidak diformalkan, tetapi tetap ada dan dikomunikasikan.

2. Risk assessment, adalah identifikasi dan analisis risiko yang relevan dengan pencapaian tujuannya entitas, membentuk dasar untuk menentukan bagaimana risiko harus dikelola.

3. Control activities adalah kebijakan dan prosedur yang membantu memastikan bahwa manajemen yang diarahkan telah dilakukan.

a. Authorization controls

Tujuan utama dari prosedur otorisasi yang tepat adalah untuk memastikan bahwa setiap transaksi disetujui oleh personil manajemen yang bertindak dalam lingkup kewenangannya.

b. Segregation of duties

Pemisahan yang kuat dari tugas melibatkan pemisahan otorisasi transaksi, mempertahankan hak atas aset, dan menjaga akuntabilitas pencatatan dalam catatan akuntansi.

Kegagalan untuk mempertahankan pemisahan tugas memungkinkan bagi seorang individu untuk melakukan kesalahan atau penipuan dan kemudian berada dalam posisi untuk menyembunyikan dalam normal kegiatan tugas yang dilakukan.

c. Information processing controls

Kontrol pengolahan informasi mengatasi risiko yang terkait dengan otorisasi, kelengkapan dan keakuratan transaksi. Kontrol ini sangat relevan dengan audit laporan keuangan. Kebanyakan entitas, terlepas dari ukurannya sekarang menggunakan komputer untuk pengolahan informasi secara umum dan pada khususnya untuk sistem akuntansi. Dalam kasus tersebut, hal ini berguna untuk lebih mengelompokan kontrol pengolahan informasi sebagai kontrol umum dan pengendalian aplikasi.

d. Physical controls

Kontrol fisik bersangkutan dengan membatasi dua jenis akses ke aset dan catatan penting yaitu akses fisik langsung dan akses langsung melalui penyusunan atau pengolahan dokumen seperti pesanan penjualan dan voucher pencairan yang mengizinkan penggunaan atau disposisi asset.

e. Performance review

Contoh penilaian kinerja meliputi tinjauan manajemen dan analisis laporan yang meringkas detail dari saldo rekening seperti neraca saldo umur piutang, laporan pengeluaran kas oleh departemen atau laporan kegiatan penjualan dan laba kotor oleh pelanggan atau wilayah, penjual, atau jajaran produk, kinerja aktual terhadap anggaran, perkiraan, atau jumlah periode sebelumnya, serta hubungan set data yang berbeda seperti data operasi nonfinancial dan data keuangan

4. Information and communication adalah identifikasi, penangkapan, dan pertukaran informasi dalam bentuk dan kerangka waktu yang memungkinkan orang untuk melaksanakan tanggung jawab mereka. 
5. Monitoring adalah proses yang menilai kualitas internal kinerja kontrol.

\section{Komponen Pengendalian Intern}

Menurut Setyawati, Agatha Gerry (2007) sistem pengendalian internal memiliki 5 komponen utama sebagai berikut:

1. Lingkungan Pengendalian. Lingkungan pengendalian merupakan sarana dan prasarana yang ada di dalam organisasi atau perusahaan untuk menjalankan struktur pengendalian internal yang baik.

2 Penaksiran Risiko. Manajemen perusahaan harus dapat mengidentifikasi berbagai risiko yang dihadapi oleh perusahaan. Dengan memahami risiko, manajemen dapat mengambil tindakan pencegahan, sehingga perusahaan dapat menghindari kerugian yang besar.

3 Aktivitas Pengendalian. Kegiatan pengawasan merupakan berbagai proses dan upaya yang dilakukan oleh manajemen perusahaan untuk menegakkan pengawasan atau pengendalian operasi perusahaan. Committee of Sponsoring Organizations (COSO) mengidentifikasi setidak-tidaknya ada lima hal yang dapat diterapkan oleh perusahaan, yaitu:

a. Pemberian otorisasi atas transaksi dan kegiatan. Otorisasi dengan cara membubuhkan tanda tangan sebagai bentuk persetujuan dari atasan.

b. Pembagian tugas dan tanggung jawab. Pembagian tugas dan tanggung jawab berdasarkan struktur organisasi yang telah dibuat perusahaan.

c. Rancangan dan penggunaan dokumen dan catatan yang baik. Dokumen sebaiknya mudah dipakai oleh karyawan, dokumen dibuat dengan bahan yang berkualitas agar bertahan lama jika disimpan.

d. Perlindungan yang cukup terhadap kekayaan dan catatan perusahaan.

e. Pemeriksaan terhadap kinerja perusahaan.

\section{Bank Perkreditan Rakyat}

Bank Perkreditan Rakyat ( BPR ) adalah salah satu jenis bank yang dikenal melayani golongan pengusaha mikro, kecil dan menengah. Dalam melaksanakan usahanya BPR berasaskan demokrasi ekonomi dengan menggunakan prinsip kehati-hatian. Demokrasi ekonomi adalah sistem ekonomi Indonesia yang dijalankan sesuai dengan pasal 33 UUD 1945 yang memiliki 8 ciri positif sebagai pendukung dan 3 ciri negatif yang harus dihindari (free fight liberalism, etatisme, dan monopoli). Menurut UU No. 10 pasal 1 ayat 2 tahun 1998 tentang perbankan, menyebutkan bahwa Bank Perkreditan Rakyat adalah bank yang melaksanakan kegiatan usaha secara konvensional atau berdasarkan prinsip syariah yang dalam kegiatannya tidak memberikan jasa lalu lintas pembayaran. Kegiatan usaha Bank Perkreditan Rakyat ditujukan untuk melayani usaha kecil dan masyarakat didaerah.Bank Perkreditan Rakyat berbentuk hukum Perseorangan Terbatas, Perusahaan Daerah atau koperasi.

Bank Perkreditan Rakyat merupakan bank yang memiliki kegiatan usaha terbatas dengan transaksi yang sederhana, meliputi penghimpunan dana dalam bentuk tabungan, deposito berjangka dan penyaluran kredit. Keterbatasan ini diberikan kepada Bank Perkreditan Rakyat terkait dengan tujuan pelayanan utama Bank Perkreditan Rakyat kepada usaha mikro kecil dan menengah serta masyarakat sekitar. Bank Perkreditan Rakyat (BPR) adalah Bank yang melaksanakan kegiatan usaha secara konvensional atau berdasarkan prinsip syariah, yang dalam kegiatannya tidak memberikan jasa dalam lalu lintas pembayaran. Kegiatan BPR jauh lebih sempit jika dibandingkan dengan kegiatan bank umum karena BPR dilarang menerima simpanan giro, kegiatan valas, dan perasuransian.

BPR adalah lembaga keuangan bank yang menerima simpanan hanya dalam bentuk deposito berjangka, tabungan, dan/atau bentuk lainnya yang dipersamakan dengan itu dan menyalurkan dana sebagai usaha BPR. BPR sudah ada sejak jaman sebelum kemerdekaan yang dikenal dengan sebutan Lumbung Desa, bank Desa, Bank Tani dan Bank Dagang Desa atau Bank Pasar.

BPR merupakan lembaga perbankan resmi yang diatur berdasarkan Undang-Undang No. 7 tahun 1992 tentang Perbankan dan sebagaimana telah diubah dengan UndangUndang No. 10 tahun 1998. Dalam undang-undang tersebut secara jelas disebutkan bawah ada dua jenis bank, yaitu Bank Umum dan BPR.

Fungsi, Tujuan dan Sasaran Bank Perkreditas Rakyat Fungsi Bank Perkreditan Rakyat adalah Penghimpun dan penyalur dana masyarakat.

Tujuan Bank Perkreditan Rakyat adalah menunjang pelaksanaan pembangunan nasional dalam rangka meningkatkan pemerataan, pertumbuhan ekonomi, dan stabilitas nasional ke arah peningkatan kesejahteraan rakyat banyak.

Sasaran Bank Perkreditan Rakyat adalah melayani kebutuhan petani, peternak, nelayan, pedagang, pengusaha kecil, pegawai, dan pensiunan karena sasaran ini belum dapat terjangkau oleh bank umum dan untuk lebih mewujudkan pemerataan layanan perbankan, pemerataan kesempatan berusaha, pemerataan pendapatan, dan agar mereka tidak jatuh ke tangan para pelepas uang (rentenir dan pengijon).

\section{Kredit}

Dalam bahasa latin kredit berarti "credere" yang artinya percaya. Pemberi kredit (kreditur) percaya kepada penerima kredit (debitur) bahwa kredit yang disalurkannya pasti akan dikembalikan sesuai perjanjian. Bagi debitur, kredit yang diterima merupakan kepercayaan, yang berarti menerima amanah sehingga mempunyai kewajiban untuk membayar sesuai jangka waktu Kasmir (2014)

Istilah kredit berasal dari bahasa Yunani "Credere" yang berarti kepercayaan, oleh karena itu dasar dari kredit adalah kepercayaan. Seseorang atau semua badan yang memberikan kredit (kreditur) percaya bahwa penerima kredit (debitur) di masa mendatang akan sanggup 
memenuhi segala sesuatu yang telah dijanjikan itu dapat berupa barang, uang atau jasa Kasmir (2014:96).

Menurut Abdullah \& Tantri (2012:163) adalah sebagai berikut: "Kredit adalah hak untuk menerima pembayaran kewajiban untuk melakukan pembayaran pada waktu diminta atau pada waktu yang akan datang, karena penyerahan barang-barang sekarang."

Menurut Drs. OP. Simorangkir dalam Untung (2000:1) kredit adalah pemberian prestasi (misalnya uang, barang) dengan balas prestasi (kontraprestasi) yang akan terjadi pada waktu yang akan datang.

Menurut Muljono, T. P. (2007:93) kredit dalam pengertian umum merupakan kepercayaan atas kemampuan pihak debitur (penerima kredit) untuk membayar sejumlah uang pada masa yang akan datang.

Menurut Kasmir (2014) kredit adalah semua jenis pinjaman yang harus dibayar kembali bersama bunganya oleh peminjam sesuai dengan perjanjian yang telah disepakati. Dengan demikian, dapat disimpulkan bahwa kredit adalah suatu usaha pemberian prestasi baik berupa barang, jasa, atau uang dari suatu pihak (pemberi kredit) kepada pihak lain (penerima kredit) atas dasar kepercayaan dimana penerima kredit harus mengembalikan kredit yang diberikan pada waktu tertentu yang akan datang disertai dengan suatu kontra prestasi (balas jasa) berupa bunga sesuai dengan perjanjian yang telah disepakati.

Kredit yang diberikan oleh bank dapat didefinisikan sebagai penyediaan uang atau tagihan yang dapat dipersamakan dengan itu, berdasarkan persetujuan atau kesepakatan pinjam-meminjam antara bank dengan pihak lain yang mewajibkan pihak peminjam untuk melunasi hutangnya setelah jangka waktu tertentu dengan jumlah bunga, imbalan atau pembagian hasil keuntungan (M. Noor, 2013 : 163).

Dari beberapa pengertian tentang kredit yang telah dikemukakan oleh para ahli di atas, maka dapat disimpulkan bahwa kredit adalah penyediaan uang atau tagihan yang dapat dipersamakan dengan itu, berdasarkan persetujuan antara pihak bank dengan pihak peminjam dengan suatu janji bahwa pembayarannya akan dilunasi oleh pihak peminjam sesuai dengan jangka waktu yang telah disepakati beserta besarnya bunga yang telah ditetapkan.

\section{Tujuan Kredit}

Menurut Muljono, T. P. (2007) mengemukakan bahwa terdapat 7 tujuan dari penyaluran kredit, anatara lain ialah untuk: 1. Memperoleh pendapatan bank ddari bunga kredit; 2. Memanfaatkan dan memproduktifkan dana-dana kredit; 3. Melaksanakan kegiatan operasional bank; 4. Memenuhi permintaan kredit dari masyarakat; 5. Memperlancar lalu lintas pembayaran; 6. Menambah modal kerja perusahaan; dan 7. Meningkatkan pendapatan dan kesejahteraan masyarakat.

\section{Prinsip-prinsip Pemberian Kredit}

Sebelum suatu fasilitas kredit diberikan, bank harus merasa yakin bahwa kredit yang diberikan benar-benar akan kembali. Keyakinan tersebut diperoleh dari hasil penilaian kredit sebelum kredit tersebut disalurkan. Prinsip perkreditan disebut juga sebagai konsep 6C (Kasmir, 2014). Pada dasarnya konsep $6 C$ ini akan dapat memberikan informasi mengenai tekad baik dan kemampuan membayar nasabah untuk melunasi kembali pinjaman beserta bunganya. Prinsip $6 C$ tersebut antara lain adalah :

1. Character. Penilaian character ini dapat mengetahui sejauh mana tingkat kejujuran dan tekad baik calon debitur yaitu kemauan untuk memenuhi kewajibankewajiban dari calon debitur.

2. Capacity. Penilaian capacity untuk melihat kemampuan dalam melunasi kewajibannya dari kegiatan usaha yang dilakukan atau kegiatan usaha yang akan dilakukan yang dibiayai dengan kredit dari bank.

3. Capital. Penilaian terhadap prinsip capital tidak hanya melihat besar kecilnya modal yang dimiliki oleh calon debitur tetapi juga bagaimana distribusi modal itu ditempatkan.

4. Collateral. Collateral diartikan sebagai jaminan fisik harta benda yang bernilai uang dan mempunyai harga stabil dan mudah dijual. Jika pada dari peminjam terkena kecelakaan atau hal-hal lain yang mengakibatkan peminjam tidak mampu membayar hutangnya, maka tindakan akhir yang dilakukan oleh bank adalah melaksanakan haknya atas collateral yang diikat secara yuridis untuk menjamin hutangnya pada bank.

5. Condition of Economy. Pada prinsip condition (kondisi), dinilai situasi dan kondisi politik, sosial, ekonomi, dan kondisi pada sektor usaha calon debitur. Maksudnya agar bank dapat memperkecil risiko yang mungkin timbul oleh kondisi ekonomi, keadaan perdagangan dan persaingan di lingkungan sektor usaha calon debitur dapat diketahui.

6. Constraint. Constraint untuk menilai budaya atau kebiasaan yang tidak memungkinkan seseorang melakukan bisnis di suatu tempat. Masalah constraint ini agak sukar dirumuskan karena tidak ada peraturan tertulis mengenai hal tersebut, dan juga tidak dapat selalu didefinisikan secara fisik permasalahannya.

Biasanya kriteria penilaian yang harus dilakukan oleh bank untuk mendapatkan nasabah yang benar-benar menguntungkan dilakukan dengan analisis $5 \mathrm{c}$ dan $7 \mathrm{p}$. Menurut Kasmir (2014) analisis dengan 5c adalah sebagai berikut:

1. Character. Suatu keyakinan bahwa, sifat atau watak dari orang-orang yang akan diberikan kredit benarbenar dapat dipercaya, hal ini tercermin dari latar belakang si nasabah baik yang bersifat latar belakang pekerjaan maupun yang bersifat pribadi

2. Capacity. Untuk melihat nasabah dalam kemampuannya dalam bidang bisinis yang dihubungkan dengan pendidikannya, kemampuan bisnis juga diukur dengan kemampuannya dalam memahami tentang ketentuanketentuan pemerintah.

3. Capital. Untuk melihat penggunaan modal apakah efektif, dilihat laporan keuangan dengan melakukan 
pengukuran seperti dari segi likuiditas, solvabilitas, rentabilitas, dan ukuran lainnya.

4. Collateral. Merupakan jaminan yang diberikan calon nasabah baik yang bersifat fisik maupun non fisik

5. Condition. Dalam menilai kredit hendaknya juga dinilai kondisi ekonomi dan politik sekarang dan di masa yang akan datang sesuai sektor masing-masing, serta prospek usaha dari sektor yang di jalankan.

Penilaian kredit dengan metode analisis $7 \mathrm{p}$ adalah sebgai berikut:

1. Personality, yaitu menilai nasabah dari segi kepribadiannya atau tingkah lakunya sehari-hari maupun masa lalunya

2. Party, yaitu mengklasifikasikan nasabah ke dalam klasifikasi tertentu atau golongan-golongan tertentu berdasarkan modal, loyalitas serta karakternya

3. Perpose, yaitu untuk mengetahui tujuan nasabah dalam mengambil kredit, termasuk jenis kredit yang diinginkan nasabah

4. Prospect, yaitu untuk menilai usaha nasabah di masa yang akan datang menguntungkan atau tidak. Hal ini penting mengingat jika suatu fasilitas kredit yang dibiayai tanpa mempunyai prospek, bukan hanya bank yang rugi, tetapi juga nasabah.

5. Payment, merupakan ukuran bagaimana cara nasabah mengembalikan kredit yang telah diambil atau dari sumber mana saja dana untuk pengembalian kredit

6. Profitability, untuk menganalisis bagaimana kemampuan nasabah dalam mencari laba

7. Protection, Tujuannya adalah bagaimana menjaga agar usaha dan jaminan mendapatkan perlindungan. Perlindungan dapat berupa jaminan barang atau orang atau jaminan asuransi.

Adapun prinsip 3R menurut Ikatan Bankir Indonesia (2014:14) adalah sebagai berikut:

1. Returns, yaitu hasil yang diperoleh debitur ketika kredit itu dimanfaatkan. Bank harus memepertimbangkan apakah kredit yang diajukan membawa manfaat sehingga debitur mampu mengembalikan kredit beserta bunga, ongkos-ongkos, dan sebagainya.

2. Repayment, yaitu pembayaran kembali. Bank harus memperhatikan kemampuan membayar kredit debitur sesuai waktu yang disediakan.

3. Risk Bearing Ability, yaitu kemampuan debitur menanggung risiko bila terjadi hal-hal diluar dugaan kedua belah pihak sehingga meyebabkan kredit menjadi macet.

Disamping penilaian dengan $5 \mathrm{C}, 7 \mathrm{P}$, dan $3 \mathrm{R}$, prinsip penilaian kredit dapat pula dilakukan dengan studi kelayakan, terutama untuk kredit dalam jumlah yang relative besar. Adapun penilaian kredit dengan studi kelayakan meliputi:

1. Aspek Hukum. merupakan aspek untuk menilai keabsahan dan keaslian dokumen-dokumen atau suratsurat yang dimiliki oleh calon debitor, seperti akte notaris, izin usaha atau sertifikat tanah dan dokumen atau surat lainnya.

2. Aspek Pasar dan Pemasaran. yaitu aspek untuk menilai prospek usaha nasabah sekarang dan di masa yang akan datang.

3. Aspek Keuangan, merupakan aspek untuk menilai kemampuan calon nasabah dalam membiayai dan mengelola usahanya. Dari aspek ini akan tergambar berapa besar biaya dan pendapatan yang akan dikeluarkan dan diperolehnya. Penilaian aspek ini dengan menggunakan rasio-rasio keuangan.

4. Aspek Operasi/Teknis. Merupakan aspek untuk menilai tata letak ruangan, lokasi usaha dan kapasitas produksi suatu usaha yang tercermin dari sarana dan prasarana yang dimilikinya.

5. Aspek Manajemen. Merupakan aspek untuk menilai sumber daya manusia yang dimiliki oleh perusahaan, baik dari segi.

\section{Prosedur Pemberian Kredit}

Prosedur pemberian dan penilaian kredit oleh dunia perbankan secara umum antar bank yang satu dengan bank yang lain tidak jauh berbeda. Prosedur pemberian kredit secara umum dapat dibedakan antara pinjaman perseorangan dengan pinjaman oleh suatu badan hukum, kemudian dapat pula ditinjau dari segi tujuannya apakah untuk konsumtif atau produktif. Prosedur pemberian kredit menurut Kasmir (2014) yaitu sebagai berikut:
a. Pengajuan berkas-berkas
b. Penyelidikan berkas pinjaman
c. Wawancara I
d. On the spot
e. Wawancara II
f. Keputusan kredit
g. Penandatanganan akad kredit atau perjanjian lainnya
h. Realisasi kredit

\section{Hasil Penelitian}

Deskripsi Prosedur Pemberian Kredit pada PT. Bank Perkreditan Rakyat (BPR) Phidectama Biak

Kredit yang diberikan oleh PT. Bank Perkreditan Rakyat (BPR) Phidectama Biak kepada anggota yaitu tujuh jenis kredit meliputi Pinjaman Kapitalisasi, Pinjaman Produktif, Pinjaman Konsumtif, Pinjaman Modal Kerja, Pinjaman Sepeda Motor, Pinjaman Rumah dan Pinjaman Pendidikan. Pinjaman Kapitalisasi diberikan dengan tujuan agar anggota aktif dalam kegiatan menabung. Pinjaman produktif bertujuan untuk membantu anggota dalam mengembangkan usaha yang dimilikinya, Pinjaman Konsumtif bertujuan untuk membantu kebutuhan konsumtif anggota. Pinjaman Modal Kerja ini diberikan dengan tujuan untuk membantu anggota mendapatkan modal usaha. Pinjaman Sepeda Motor memiliki tujuan untuk membantu anggota dalam mendapatkan kendaraan bermotor yang diinginkan, Pinjaman Rumah ini bertujuan untuk memfasilitasi anggota dalam mendapatkan rumah, sedangkan Pinjaman Pendidikan memfasilitasi anggota untuk meningkatkan pendidikan bagi dirinya dan keluarga dari anggota tersebut. 
Supaya aktivitas kredit ini dapat berjalan dengan baik dan lancar maka diperlukan suatu sistem kredit yang sesuai dengan kebijakan $\mathrm{CU}$ yang mampu menjamin keberlangsungan kredit tersebut. Untuk menjawab permasalahan pertama mengenai prosedur sistem pemberian kredit, berikut ini akan diuraikan deskripsi dan analisis dari data yang diperoleh dalam penelitian.

1. Prosedur-prosedur pemberian kredit pada PT. Bank Perkreditan Rakyat (BPR) Phidectama Biak

a. Pengajuan Kredit

Calon debitur yang akan melakukan peminjaman di PT. Bank Perkreditan Rakyat (BPR) Phidectama Biak harus sudah menjadi anggota PT. Bank Perkreditan Rakyat (BPR) Phidectama Biak kurang lebih 3 bulan dan untuk anggota yang berumur di bawah 17 tahun tidak diperbolehkan untuk meminjam. Ketika calon debitur datang, mereka akan dilayani langsung oleh bagian kredit yang bertugas untuk memberikan berbagai macam informasi mengenai syarat dan ketentuan permohonan kredit. Anggota akan diminta untuk mengisi surat permohonan pinjaman (SPP). Setelah mengisi SPP, anggota harus melengkapi persyaratan seperti fotokopi KTP (suami dan/atau istri), fotokopi kartu keluarga, fotokopi surat nikah, fotokopi slip gaji, fotokopi rekening listrik, fotokopi sertifikat DIKSAR (semua anggota wajib untuk mengikuti Pendidikan Dasar yang diselenggarakan oleh PT. Bank Perkreditan Rakyat (BPR) Phidectama Biak). Jumlah pinjaman yang dapat diajukan oleh anggota yaitu sebesar sepertiga (1/3) dari tabungan atau bila belum mencukupi, anggota wajib untuk menambah tabungannya terlebih dahulu. Sedangkan pengajuan pinjaman untuk pinjaman kendaraan bermotor dan pinjaman rumah anggota diharuskan menabung sebanyak 10 kali terlebih dahulu. Jika berkas sudah lengkap maka selanjutnya bagian kredit akan melakukan penyidikan dan menganalisa.

b. Penyidikan dan Analisa Kredit

Pada tahap ini, bagian kredit akan melakukan pemeriksaan ke lapangan untuk mengetahui kondisi calon debitur yang sebenarnya dengan melakukan wawancara dan memeriksa jaminan yang digunakan sebagai jaminan kepada bank. Setelah bagian kredit meneliti berkas dan keadaan di lapangan, kemudian akan mengisi form Hasil Survei Anggota (HSA).

c. Keputusan Kredit

Pada tahap keputusan kredit kepala kantor, bagian kredit dan bagian kasir akan melakukan rapat yang bertujuan untuk memutuskan apakah permohonan calon debitur disetujui atau tidak. Berkas-berkas permohonan peminjaman yang telah dianalisa oleh kepala kantor, bagian kredit dan kasir akan digunakan sebagai bahan pertimbangan dalam pengambilan keputusan atas permohonan pinjaman. Dibawah ini akan dijelaskan mengenai prosedur keputusan peminjaman:
1) Keputusan peminjaman ditolak

Bagian kredit akan menghubungi anggota melalui telepon dan memberitahukan bahwa pengajuan pinjamannya ditolak.

2) Keputusan peminjaman disetujui

Bagian kredit akan mengisi form persetujuan pinjaman terlebih dahulu setelah itu menghubungi anggota untuk datang ke tempat pelayanan untuk melengkapi Berita Acara Serah Terima Jaminan (BASTJ) dan menandatangani Surat Perjanjian Pinjaman (SPP) serta debitur diharuskan untuk membawa jaminan asli (STNK asli/surat tanah asli). Penandatanganan SPP dilakukan di hadapan notaris dan kepala kantor. Setelah semua selesai, anggota akan diberi perhitungan angsuran untuk setiap bulannya.

d. Pencairan Kredit

Pada tahap ini, bagian yang berkewajiban untuk mecairkan pinjaman adalah bagian kasir. Bagian kasir akan mencairkan pinjaman apabila sudah menerima laporan analisis kredit dari bagian kredit. Setelah itu bagian kasir akan menyiapkan uang dan menyerahkan pinjaman kepada debitur sesuai dengan nominal yang tertera dalam slip pencairan pinjaman.

e. Pelunasan Kredit

Pelunasan kredit dari para debitur dilakukan oleh bagian kasir. Jika pinjaman dan bunga angsuran telah dilunasi oleh debitur maka jaminan akan diberikan langsung kepada pihak debitur.

2. Dokumen-dokumen dan catatan yang terdapat pada PT. Bank Perkreditan Rakyat (BPR) Phidectama Biak:

a. Surat Permohonan Pinjaman

Surat permohonan pinjaman ini berisikan data diri anggota, data suami/istri (bila telah menikah), data keuangan anggota yang ada di PT. Bank Perkreditan Rakyat (BPR) Phidectama Biak, jumlah pinjaman yang diajukan, jenis pinjaman dan tujuan pinjaman, jangka waktu pembayaran serta anggaran pendapatan dan belanja keluarga per bulan.

Formulir surat permohonan pinjaman ini telah disiapkan oleh PT. Bank Perkreditan Rakyat (BPR) Phidectama Biak untuk diisi dan dilengkapi oleh calon debitur bila mengajukan pinjaman.

b. Hasil Survei Anggota

Dokumen ini berisi mengenai penilaian survei yang telah dilakukan oleh bagian kredit dalam mewawancarai tetangga dan dengan melihat langsung keadaan di lapangan. Dokumen ini harus berisikan mengenai informasi-informasi yang menyangkut kesehatan kredit, baik mengenai reputasi dan kondisi calon debitur, rencana penggunaan dana, prospek usaha (bila untuk membangun atau mengembangkan usaha), barang jaminan serta rencana pengembalian fasilitas kredit yang akan diberikan oleh calon debitur. 
c. Persetujuan Pinjaman

Dokumen ini berisikan analisis berdasarkan permohonan pinjaman dengan memperhatikan kelengkapan administrasi, total nilai analisis tukkepar, total nilai analisis 5-C, catatan dari bagian kredit yang telah dirapatkan. Dalam dokumen ini pula diputuskan besar nilai pinjaman yang disetujui oleh pihak PT. Bank Perkreditan Rakyat (BPR) Phidectama Biak.

d. Berita Acara Serah Terima Jaminan

Dokumen ini berisi mengenai penyerahan jaminan berupa STNK asli, sertifikat tanah dan bangunan kepada PT. Bank Perkreditan Rakyat (BPR) Phidectama Biak yang dilakukan oleh debitur. Apabila pinjaman beserta bunga angsuran telah dilunasi oleh debitur, maka jaminan akan langsung

Tabel 1

Rangkuman Analisis Pelaksanaan Pengendalian Intern Pada Proses Pemberian Kredit Berdasarkan Pengendalian Intern pada

\begin{tabular}{|c|c|c|c|}
\hline \multicolumn{4}{|c|}{ COSO } \\
\hline Komponen & Teori COSO & $\begin{array}{c}\text { Praktik Pengendalian yang } \\
\text { Dilaksanakan PT. BPR } \\
\text { Phidectama Biak }\end{array}$ & Sesuai / Tidak Sesuai \\
\hline \multirow[t]{5}{*}{$\begin{array}{l}\text { Lingkungan } \\
\text { Pengendalian }\end{array}$} & Kode etik karyawan & $\begin{array}{l}\text { BPR Phidectama Biak memiliki } \\
\text { kode etik secara tertulis untuk } \\
\text { pengelola (pengurus, pengawas } \\
\text { dan manajemen) }\end{array}$ & Sesuai \\
\hline & \begin{tabular}{|l|}
$\begin{array}{l}\text { Pengomunikasian terhadap } \\
\text { pelanggaran }\end{array}$ \\
\end{tabular} & 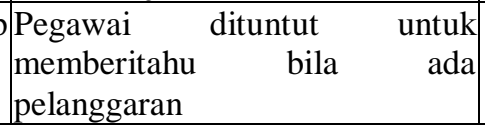 & Sesuai \\
\hline & $\begin{array}{l}\text { Bimbingan moral kepada } \\
\text { pegawai }\end{array}$ & $\begin{array}{l}\text { Bimbingan moral dilakukan } \\
\text { dengan sharing atau ibadah dan } \\
\text { pertemuan koordinasi ditutup } \\
\text { dengan doa bersama }\end{array}$ & Sesuai \\
\hline & $\begin{array}{l}\text { Hukuman } \\
\text { pelanggaran }\end{array}$ & $\begin{array}{l}\text { Hukuman atau Punishment } \\
\text { diberikan kepada pegawai yang } \\
\text { melakukan fraud }\end{array}$ & Sesuai \\
\hline & Pelatihan pegawai & $\begin{array}{lll}\text { PT. BPR Phidectama } & \text { Biak } \\
\text { melaksanakan pelatihan } & \text { bagi } \\
\text { pegawai sesuai kebutuhan. } & \end{array}$ & Sesuai \\
\hline
\end{tabular}

(Sumber: COSO Framework, 2020)

Pengendalian intern terhadap pemberian kredit, PT. Bank Perkreditan Rakyat (BPR) Phidectama Biak telah menerapkan 1 (satu) komponen pengendalian yang ditetapkan COSO, yaitu lingkungan pengendalian. PT. Bank Perkreditan Rakyat (BPR) Phidectama Biak sudah melakukan semua kegiatan yang terdapat di komponen lingkungan pengendalian dengan mempraktikkan kegiatan seperti melayani anggota dengan pelayanan dikembalikan kepada pemilik.

e. Surat Perjanjian Pinjaman

Dokumen ini berisi perjanjian yang mengatur ketentuan-ketentuan mengenai fasilitas pinjaman, pembayaran pinjaman, jaminan, kuasa-kuasa dan ketentuan lainnya.

Deskripsi implementasi sistem pengendalian intern pemberian kredit yang terdapat pada PT. Bank Perkreditan Rakyat (BPR) Phidectama Biak sesuai dengan unsur pengendalian intern menurut COSO

Berdasarkan informasi yang telah diperoleh dengan cara melakukan wawancara kepada bagian kredit. Pelaksanaan pengendalian kredit dapat diuraikan sebagai berikut:

a. Lingkungan Pengendalian

COSO 
Tabel 2

Rangkuman Analisis Pelaksanaan Pengendalian Intern Pada Proses Pemberian Kredit Berdasarkan Pengendalian Intern pada COSO

\begin{tabular}{|c|c|c|c|}
\hline Komponen & Teori COSO & $\begin{array}{c}\text { Praktik Pengendalian yang Dilaksanakan } \\
\text { PT. BPR Phidectama Biak }\end{array}$ & $\begin{array}{c}\text { Sesuai / Tidak } \\
\text { Sesuai }\end{array}$ \\
\hline \multirow[t]{4}{*}{ Penilaian Resiko } & Personil baru & $\begin{array}{l}\text { Perekrutan personel baru diadakan bila } \\
\text { ada bagian yang membutuhkan }\end{array}$ & Sesuai \\
\hline & Sistem informasi yang baru & $\begin{array}{l}\text { Sistem informasi yang baru memudahkan } \\
\text { kantor pusat untuk mengkontrol setiap } \\
\text { kantor pelayanan dan lebih efisien }\end{array}$ & Sesuai \\
\hline & Teknologi baru & $\begin{array}{l}\text { PT. BPR Phidectama Biak selalu } \\
\text { melakukan upgrade IT demi kelancaran } \\
\text { pelayanan kepada anggota }\end{array}$ & Sesuai \\
\hline & Produk dan aktivitas baru & $\begin{array}{l}\text { PT. BPR Phidectama Biak selalu } \\
\text { mengupayakan ketepatan dan kecepatan } \\
\text { dalam pelayanan kepada anggota dengan } \\
\text { memanfaatkan kemajuan teknologi. } \\
\text { Pegawaipun dituntut semakin produktif } \\
\text { dalam melakukan pelayanan kepada } \\
\text { anggota }\end{array}$ & Sesuai \\
\hline
\end{tabular}

\section{(Sumber: COSO Framework, 2020)}

Komponen pengendalian intern yang diterapkan COSO yang ke-2, yaitu penilaian risiko yang telah diterapkan oleh PT. BPR Phidectama Biak. Dalam melakukan penilaian risiko, PT. BPR Phidectama Biak selalu melakukan penilaian risiko terhadap pegawai atau personel baru apabila dibutuhkan dalam bidang tertentu, menerapkan sistem informasi yang baru untuk memudahkan dalam mengkontrol dan lebih efisien. PT.

Tabel 3

Rangkuman Analisis Pelaksanaan Pengendalian Intern Pada Proses Pemberian Kredit Berdasarkan Pengendalian Intern COSO

\begin{tabular}{|c|c|c|c|c|}
\hline Komponen & Teori COSO & $\begin{array}{l}\text { Praktik Pengendalian yang } \\
\text { Dilaksanakan PT. BPR } \\
\text { Phidectama Biak }\end{array}$ & $\begin{array}{l}\text { Sesuai / Tidak } \\
\text { Sesuai }\end{array}$ & Keterangan \\
\hline \multirow[t]{4}{*}{$\begin{array}{l}\text { Aktivitas } \\
\text { Pengendalian }\end{array}$} & \multicolumn{2}{|c|}{$\begin{array}{l}\text { Pelaksana kredit Pelaksana kredit tidak terpisah } \\
\text { harus terpisah dari dengan pembahas kredit } \\
\text { pembahaas kredit }\end{array}$} & Tidak Sesuai & $\begin{array}{l}\text { Adanya peluang } \\
\text { untuk melakukan } \\
\text { penyalahgunaan } \\
\text { wewenang }\end{array}$ \\
\hline & \multicolumn{2}{|c|}{$\begin{array}{|ll|}\text { Pelaksanaan } & \text { kredit } \\
\text { harus terpisah } & \text { dari dengan penyidikan dan analisa } \\
\text { penyidikan } & \text { dan } \\
\text { analisa kredit } & \end{array}$} & Tidak Sesuai & $\begin{array}{l}\text { Adanya peluang } \\
\text { untuk melakukan } \\
\text { penyalahgunaan } \\
\text { wewenang, bisa } \\
\text { saja kredit yang } \\
\text { akan dicairkan } \\
\text { tidak tepat sasaran }\end{array}$ \\
\hline & \multicolumn{2}{|c|}{$\begin{array}{l}\text { Bagian administrasiBagian administrasi kredit dan } \\
\text { dan } \quad \text { pembukuankasir terpisah. } \\
\text { kredit harus terpisah } \\
\text { dari kasir }\end{array}$} & Sesuai & \\
\hline & \multicolumn{2}{|c|}{\begin{tabular}{|l|lrl|} 
Terdapat lebih dari & PT. BPR & Phidectama & Biak \\
satu bagian yang & memiliki tiga bagian yang \\
bertanggungjawab & bertanggungjawab atas seluruh \\
atas seluruh tahap & tahap transaksi kredit yaitu \\
transaksi kredit & $\begin{array}{l}\text { Bagian kredit, koordinator dan } \\
\text { bagian kasir. }\end{array}$ \\
\end{tabular}} & Sesuai & \\
\hline
\end{tabular}

Bank Perkreditan Rakyat (BPR) Phidectama Biak selalu melakukan upgrade IT untuk kelancaran pelayanan terhadap anggota, dan dengan adanya teknologi yang baru maka diharapkan mempercepat dalam pelayanan kepada anggota dan meningkatkan produktivitas pegawai.

c. Aktivitas Pengendalian 


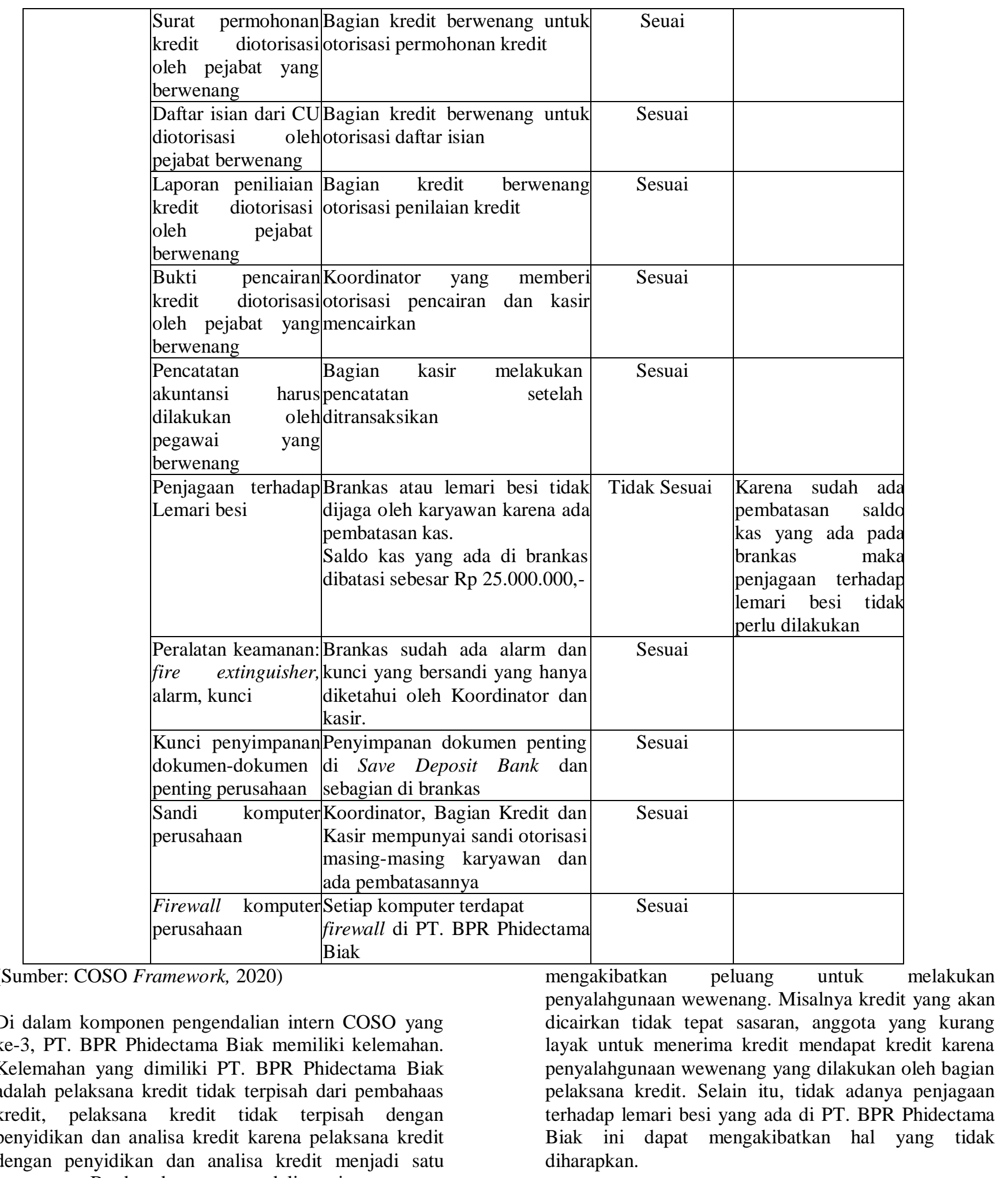
kesatuan. Berdasarkan pengendalian intern yang diterapkan oleh COSO, seharusnya pelaksana kredit harus terpisah dari bagian penyidikan dan analisa d. Informasi dan Komunikasi kredit. Apabila hal ini tetap diterapkan, maka akan 
Tabel 4

Rangkuman Analisis Pelaksanaan Pengendalian Intern Pada Proses Pemberian Kredit Berdasarkan Pengendalian Intern pada COSO

\begin{tabular}{|c|c|c|c|}
\hline Komponen & Teori COSO & \begin{tabular}{|c|} 
Praktik Pengendalian yang \\
Dilaksanakan PT. BPR Phidectama \\
Biak
\end{tabular} & $\begin{array}{l}\text { Sesuai / Tidak } \\
\text { Sesuai }\end{array}$ \\
\hline \multirow[t]{5}{*}{$\begin{array}{l}\text { Informasi dan } \\
\text { Komunikasi }\end{array}$} & Terdapat surat permohonan kredit & $\begin{array}{l}\text { Surat permohonan kredit sudah ada } \\
\text { di PT. BPR Phidectama Biak }\end{array}$ & Sesuai \\
\hline & Terdapat surat keputusan kredit & $\begin{array}{|lll|}\begin{array}{l}\text { Setelah dirapatkan ada surat } \\
\text { keputusan kredit }\end{array} & & \\
\end{array}$ & Seusai \\
\hline & Terdapat dokumen perjanjian kredit & $\begin{array}{l}\text { Pada saat pencairan kredit } \\
\text { perjanjian kredit yang } \\
\text { ditandatangani oleh anggota }\end{array}$ & Sesuai \\
\hline & Terdapat bukti pencairan kredit & $\begin{array}{l}\text { Slip uang keluar dan kwitansi } \\
\text { sebagai bukti pencairan kredit }\end{array}$ & Sesuai \\
\hline & $\begin{array}{l}\text { Pencatatan terjadinya transaks } \\
\text { didasarkan atas bukti pencairan kredi } \\
\text { yang didukung dengan sura } \\
\text { permohonan, surat keputusan, dar } \\
\text { dokumen perjanjian kredit }\end{array}$ & $\begin{array}{l}\text { Proses pencairan kredit yang } \\
\text { terakhir dengan transaksi yang } \\
\text { didukung dengan permohonan, } \\
\text { keputusan dan perjanjian kredit }\end{array}$ & Sesuai \\
\hline
\end{tabular}

(Sumber: COSO Framework, 2020)

PT. BPR Phidectama Biak telah menerapkan komponen pengendalian intern yang diterapkan COSO ke-4 yaitu informasi dan komunikasi. Hal itu dapat dilihat dengan adanya surat permohonan kredit. Surat keputusan kredit, dokumen perjanjian kredit, bukti pencairan kredit serta adanya pencatatan transaksi yang sudah diproses dan didukung oleh surat permohonan kredit, surat

Tabel 5

Rangkuman Analisis Pelaksanaan Pengendalian Intern Pada Proses Pemberian Kredit Berdasarkan Pengendalian Intern pada COSO

\begin{tabular}{|c|c|c|c|}
\hline Komponen & Teori COSO & $\begin{array}{c}\text { Praktik Pengendalian yang } \\
\text { Dilaksanakan PT. BPR } \\
\text { Phidectama Biak }\end{array}$ & $\begin{array}{c}\text { Sesuai / Tidak } \\
\text { Sesuai }\end{array}$ \\
\hline \multirow[t]{3}{*}{ Pemantauan } & Prosedur pemberian kredit & $\begin{array}{l}\text { Pemberian kredit dilaksanakan } \\
\text { sesuai dengan peraturan yang } \\
\text { ada }\end{array}$ & Sesuai \\
\hline & $\begin{array}{l}\text { Secara periodik dilakukan evaluasi } \\
\text { kinerja bagian perkreditan }\end{array}$ & $\begin{array}{l}\text { Setiap awal bulan dilakukan } \\
\text { evaluasi pada bagian kredit }\end{array}$ & Sesuai \\
\hline & $\begin{array}{l}\text { Adanya pemantauan langsung } \\
\text { terhadap proses pemberian kredit }\end{array}$ & $\begin{array}{l}\text { Pemantauan terhadap proses } \\
\text { kredit dilakukan setiap bulannya }\end{array}$ & Sesuai \\
\hline
\end{tabular}

(Sumber: COSO Framework, 2020)

Komponen ke-5 pengendalian intern yang diterapkan COSO yaitu pemantauan telah diterapkan pada PT. BPR Phidectama Biak. Pemantauan dilakukan secara langsung terhadap pemberian kredit sesuai dengan prosedur pemberian kredit sesuai dengan peraturan yang telah diterapkan. Pemantauan ini dilaksanakan setiap bulan yaitu pada saat evaluasi kinerja pada bagian kredit.

Berdasarkan analisis tersebut dapat disimpulkan bahwa sebagian besar sistem pengendalian intern pada proses pemberian kredit yang dilakukan PT. BPR Phidectama Biak telah sesuai dengan pengendalian intern yang diterapkan COSO, kecuali dalam hal aktivitas keputusan kredit dan surat perjanjian kredit. Dokumendokumen ini sangat mendukung proses informasi dan komunikasi antara pihak bank dan anggota yang melakukan permohonan kredit.

e. Pemantauan

pengendalian. Hal ini terbukti dalam komponen aktivitas pengendalian terdapat 14 kegiatan yang seharusnya dilakukan, namun ada 2 kegiatan dalam komponen aktivitas pengendalian tidak dilakukan sesuai dengan COSO. PT. BPR Phidectama Biak tidak melakukan pemisahan tugas antara pelaksana kredit dan bagian penyidikan serta bagian analisa kredit. Selain itu, di PT. BPR Phidectama Biak brankas atau lemari besi tidak ada yang menjaga. Pemisahan tugas dan penjagaan terhadap lemari besi sangatlah penting agar tidak terjadi pelanggaran yang tidak diharapkan.

\section{Prosedur Pemberian Kredit}

Prosedur pemberian kredit adalah langkah-langkah yang harus dilalui dalam pemberian kredit. Tujuan prosedur 
pemberian kredit adalah untuk meminimalkan risiko-risiko yang harus ditanggung oleh PT. BPR Phidectama Biak dalam memberikan kredit. Prosedur pemberian kredit di PT. BPR Phidectama Biak dapat diilustrasikan dan dijelaskan sebagai berikut:

\section{a. Permohonan Kredit}

Permohonan kredit di PT. BPR Phidectama Biak diterima dan dilakukan pengecekan persyaratan yang dibawa nasabah oleh CS (Customer Service). Persyaratan yang dibawa apabila kurang lengkap maka permohonan kredit tersebut harus dilengkapi terlebih dahulu dan apabila persyaratan lengkap, maka customer service menerima permohonan tersebut dan meneruskan berkas tersebut kepada atasannya.

Permohonan kredit ada beberapa yang diajukan oleh calon nasabah yang mempunyai kedekatan dengan pegawai, adanya kedekatan tersebut memberi peluang besar disetujuinya permohonan kredit. Permohonan kredit yang diajukan dengan faktor kedekatan dengan pegawai ini, tetap harus dengan persyaratan lengkap. Syarat yang harus dilengkapi oleh calon pemohon kredit sebagai berikut:

1. Kredit Umum

a) Fotokopi KTP suami dan istri

b) Fotokopi Kartu Keluarga

c) Fotokopi Nomor Pokok Wajib Pajak (NPWP)

d) Mengisi Blanko Kredit (sudah disediakan oleh Bank)

e) BPKB asli dan fotokopi

f) Fotokopi STNK

g) Fotokopi bukti lunas pajak kendaraan

h) Sertifikat Hak Milik/Sertifikat Hak Guna Bangunan asli dan fotokopi

i) Fotokopi pembayaran PBB

2. Kredit Multiguna/TNI/POLRI/PNS

a) Rekomendasi dari instansi yang bersangkutan

b) Surat Kuasa Pemotongan Gaji

c) Surat Keterangan Gaji/Pendapatan

d) Surat Pernyataan Debitur

e) Surat Pernyataan Bendahara Gaji

f) Fotokopi SK Pengangkatan (CPNS, PNS, BUMN, BUMD, Swasta, Pensiunan, Honorer) yangtelah dilegalisir pejabat yang berwenang

g) Fotokopi Surat Keputusan Terakhir yang dilegalisir

h) 1 lembar fotokopi Kartu Pegawai (Negeri, Swasta) yang telah dilegalisir pejabat yang berwenang

i) lembar fotokopi KTP Suami dan Istri

j) 1 lembar fotokopi KSK

k) lembar foto ukuran $4 \times 6$

1) Fotokopi bukti kepemilikan jaminan tambahan

m) Slip Gaji yang telah dilegalisir

\section{b. Analisis Peninjauan Nasabah}

Analis peninjauan nasabah dilakukan dengan tujuan memastikan bahwa data yang diperoleh dari calon nasabah sesuai dengan kenyataan di lapangan. Kegiatan penganalisisan meninjau nasabah ini tidak dilakukan secara langsung kepada nasabah, tetapi dilakukan wawancara dengan orang rumah sekitar. Misalnya tetangga calon nasabah. Analisis meninjau nasabah ini dilakukan untuk meninjau jaminan yang dijaminkan apakah sesuai dengan nilai permohonan kredit yang diajukan.

c. Analis Laporan Hasil Peninjauan Nasabah

Pihak bank membuat laporan mengenai riwayat kredit calon nasabah, karakter calon nasabah, nilai jaminan yang dijaminkan, dan kemampuan calon nasabah dalam pelunasan kreditnya apabila permohonan kredit disetujui.

\section{d. Keputusan Kredit}

Keputusan kredit dilakukan setelah membuat laporan hasil analis, kemudian disampaikan kepada yang mempunyai kewenangan. Keputusan kredit di PT. BPR Phidectama Biak dilakukan oleh pejabat sebagai berikut:

1) Penyelia diberikan kewenangan memberikan kredit sebesar maksimal Rp 50.000.000,00 (lima puluh juta rupiah).

2) Pimpinan cabang diberikan kewenangan memberikan kredit sebesar maksimal Rp 100.000.000,00 (seratus juta rupiah).

3) Direksi diberikan kewenangan memberikan kredit sebesar maksimal Rp 500.000.000,00 (lima ratus juta rupiah).

\section{e. Persetujuan Permohonan Kredit}

Bagian administrasi menyiapkan dokumen-dokumen yang dibutuhkan setelah diberi keputusan persetujuan permohonan kredit oleh pejabat yang berwenang dalam perjanjian kredit dan pencairan kredit, setelah dokumen perjanjian selesai diproses maka disampaikan kepada CS (Customer Service) untuk diinformasikan kepada nasabah untuk datang dan menandatangani dokumen perjanjian kredit.

f. Pencairan Kredit

Proses perjanjian kredit selesai kemudian adalah pencairan kredit. Proses penandatanganan kredit apabila lancar dan dokumen lengkap, maka kredit bisa dicairkan.

g. Hambatan-hambatan dalam Prosedur Pemberian Kredit

Tahap proses pemberian kredit pada PT. BPR Phidectama Biak terdapat hambatan-hambatan yang dilalui. Hambatan tersebut dalam hal proses pemberian persetujuan kredit kepada calon nasabah. Hambatan tersebut dapat diuraikan sebagai berikut:

1. Faktor kedekatan pegawai dengan calon nasabah Berdasarkan hasil wawancara yang dilakukan bahwa terdapat faktor kedekatan antara pegawai dengan calon nasabah. Faktor kedekatan ini memengaruhi disetujuinya permohonan kredit yang diajukan. Faktor kedekatan ini memengaruhi disetujuinya permohonan kredit yang diajukan, kedekatan yang dimaksud disini adalah apabila adanya faktor keluarga yang bekerja di PT. BPR Phidectama Biak atau memiliki hubungan baik dengan pegawai PT. BPR Phidectama Biak, sehingga permohonan kredit akan mudah untuk disetujui oleh pihak bank, tetapi faktor kedekatan ini tidak memengaruhi mengenai persyaratan yang harus dilengkapi. Faktor dekat atau tidak dengan pegawai syarat-syarat pengajuan kredit 
tetap harus dilengkapi sesuai prosedur yang telah ditetapkan.

2. Persyaratan tidak lengkap dalam pengajuan permohonan kredit Permohonan kredi pada PT. BPR Phidectama Biak, apabila persyaratan tidak lengkap disebabkan karena calon nasabah yang tidak teliti dalam membaca persyaratan yang diperlukan. Persyaratan yang kurang ini, nantinya akan menunda proses permohonan kredit sampai persyaratan yang disyaratkan dipenuhi. Contoh konkret yang biasa terjadi di PT. BPR Phidectama Biak adalah untuk yang kredit umum atau UMKM mereka terkendala dengan tidak adanya atau belum membayar pajak tanah dan pajak sepeda motor yang belum dilunasi pembayarannya, sehingga nasabah harus mengurusnya terlebih dahulu.

3. Informasi palsu yang diberikan oleh calon nasabah Informasi palsu banyak diberikan oleh calon nasabah agar permohonan kredit diloloskan. Informasi yang tidak sesuai ini nantinya juga akan menghambat proses selanjutnya dalam prosedur pemberian kredit. Informasi kredit ini biasanya akan terlihat pada saat kunjungan yang dilakukan oleh pihak bank. Contoh konkret yang sering terjadi di PT. BPR Phidectama Biak yaitu jaminan pada sertifikat tanah tidak sesuai dengan syarat, misalnya tempat usaha yang di tengah sawah, tidak memiliki akses jalan, dan di dekat tepi sungai. Tanah sawah seringkali banyak yang tidak ada jalan akses masuk. Nasabah terdapat ada yang menipu diri sendiri seolah-olah dia mampu akan tetapi sebenarnya tidak mampu.

h. Cara Mengatasi Hambatan di PT. BPR Phidectama Biak adalah sebagai berikut:

1. Faktor kedekatan pegawai dengan calon nasabah Cara yang dilakukan oleh PT. BPR Phidectama Biak yakni untuk meminimalkan kredit yang disetujui karena ada kedekatan dengan pegawai adalah dengan cara menumbuhkan sikap kehati-hatian dan sikap profesional terhadap para petugas analis lapangan dalam praktik keseharian bertugas. Sikap kehatihatian dan sikap profesional ini apabila telah dipraktikkan maka praktik kolusi yang disebabkan oleh faktor kedekatan tidak akan dipraktikkan kembali, selain itu pihak bank lebih teliti dan selektif pada saat survei lapangan atau survei lebih mendalam terkait calon nasabah yang mengajukan permohonan kredit dengan melihat benar kondisi perekonomian atau usaha yang sebenarnya dimiliki oleh nasabah tersebut.

Pihak bank perlu melakukan rotasi jabatan berkala yang dapat dilakukan setidaknya 2 tahun sekali masa jabatan para pegawainya. Tujuan dari langkah ini yakni untuk meminimalisir terjadinya kecurangan dari pihak bagian bekerja di lapangan yang memiliki kedekatan khusus dengan calon nasabah.

2. Persyaratan tidak lengkap dalam pengajuan permohonan kredit

Langkah yang dilakukan oleh PT. BPR Phidectama Biak untuk mengatasi persyaratan tidak lengkap adalah mengecek terlebih dahulu permohonan kredit apakah sudah sesuai dengan persyaratan atau belum. Persyaratan yang kurang apabila ditemukan, maka pihak bank akan meminta calon nasabah tersebut untuk melengkapi persyaratan yang dibutuhkan

3. Informasi palsu yang diberikan oleh calon nasabah Langkah untuk mengatasi hambatan ini, dengan melakukan kunjungan, dengan tujuan memastikan informasi yang diberikan benar. Pihak bank memastikan benar bahwa pegawai analis lapangan tidak memiliki kedekatan dengan calon nasabah supaya tidak terjadi lagi adanya manipulasi data dengan faktor kedekatan pada pegawai bank, selanjutnya pegawai analis langsung meninjau lokasi. Nasabah apabila memiliki usaha maka pihak bank langsung meninjau lokasi keadaan usaha nasabah yang meminjam kredit. Petugas survei melakukan pendekatan terkait dengan kegiatan sehari-hari nasabah dengan mencari informasi-informasi seperti jenis usaha, sejak usaha tersebut didirikan, dan tujuan nasabah melakukan kredit ke bank. Pihak pegawai analis lapangan biasanya mencari informasi melalui tetangga nasabah untuk mengetahui character nasabah tersebut. Informasi apabila ditemukan palsu dari calon nasabah, maka pihak bank mencari solusi dari letak masalah dan pihak bank akan memanggil nasabah dan melakukan wawancara terhadap nasabah. Nasabah yang ditemukan bermasalah maka pihak bank menawarkan untuk menyelesaikan masalah secara kekeluargaan dahulu, apabila tidak terima maka akan diselesaikan lewat jalur hukum.

\section{Implementasi Sistem Pengendalian Intern Pemberian Kredit}

Penelitian ini dilakukan untuk mengetahui apakah sistem pengendalian intern pemberian kredit di PT. Bank Perkreditan Rakyat (BPR) Phidectama Biak sudah efektif. Untuk mengetahui efektif atau tidaknya sistem pengendalian intern pemberian kredit tersebut dilakukan dengan cara mengevaluasi unsur-unsur dan pelaksanaan sistem pengendalian intern pemberian kredit yang telah ditentukan oleh perusahaan kemudian membandingkan pelaksanaan sistem pengendalian intern pemberian kredit yang baik.

Sistem pengendalian intern pemberian kredit di PT. Bank Perkreditan Rakyat (BPR) Phidectama Biak belum sepenuhnya dilaksanakan secara memadai. Sudah ada struktur organisasi dan pembagian wewenang akan tetapi, masih terdapat perangkapan tugas dibagian-bagian tertentu. Berdasarkan hasil penelitian, maka dapat diuraikan mengenai sistem pengendalian intern pemberian kredit di PT. Bank Perkreditan Rakyat (BPR) Phidectama Biak dilakukan untuk tiap elemen pengendalian intern yang terdiri dari lingkungan pengendalian, penaksiran risiko, informasi dan komunikasi, aktivitas pengendalian, dan pemantauan.

1. Lingkungan pengendalian 
Lingkungan pengendalian ini merupakan tindakan kebijakan dan prosedur yang mencerminkan keseluruhan sikap manajemen tentang pengendalian dan pentingnya organisasi. Dalam cakupan komponen yang berhubungan dengan lingkungan pengendalian meliputi:

a. Nilai integritas dan etika

Nilai integritas dan etika merupakan produk dari standar perilaku dan etika suatu entitas serta bagaimana hal tersebut dikomunikasikan dan ditetapkan dalam praktek. Semua personel harus menjunjung tinggi nilai integritas dan etika yang berlaku dalam lingkungan perusahaan. PT. Bank Perkreditan Rakyat (BPR) Phidectama Biak sesuai dengan apa yang ada didalam tabulasi kuesioner telah menerapkan peraturan yang harus dipenuhi oleh karyawan perusahaan, dan untuk mendorong praktek yang sehat manajemen berusaha menghilangkan hal-hal yang biasa mendorong masing-masing personel berlaku menyimpang dari aturan dan kebijakan organisasi, maka perusahaan akan memberikan sanksi bagi yang melanggar peraturan yang telah diterapkan oleh perusahaan perusahaan tersebut. Dengan adanya peraturan tersebut maka perusahaan dapat mendorong karyawan untuk tidak melakukan tindakan yang tidak jujur, ilegal dan tidak memenuhi syarat yang dapat merugikan perusahaan.

b. Komitmen terhadap kompetensi

Personel di setiap tingkat organisasi harus memiliki pengetahuan dan keterampilan yang diperlukan untuk melaksanakan tugasnya secara efektif. Komitmen terhadap kompetensi mencakup pertimbangan manajemen atas pengetahuan dan keterampilan yang diperlukan, dan paduan antara kecerdasan, pelatihan, dan pengalaman yang dituntut dalam pengembangan kompetensi. PT. Bank Perkreditan Rakyat (BPR) Phidectama Biak sesuai dengan apa yang ada dalam tabulasi kuesioner telah memiliki komitmen terhadap kompetensi yang mencakup pertimbangan manajemen atas pengetahuan dan keterampilan yang diperlukan, paduan kecerdasan, pelatihan dan pengalaman yang dituntut dalam pengembangan kompetensi. Karyawan juga telah memiliki pengetahuan dan keterampilan yang diperlukan untuk melaksanakan tugasnya secara efektif.

c. Dewan komisaris dan komite audit

Dewan komisaris merupakan wakil dari pemegang saham, sedangkan komite audit dibentuk untuk mengawasi proses laporan keuangan. PT. Bank Perkreditan Rakyat (BPR) Phidectama Biak memiliki dewan komisaris dan komite audit. Komite audit ditunjuk oleh dewan komisaris. Komite audit juga mempunyai kekuatan yang independen sehingga dipercaya oleh masyarakat memiliki kewajaran pertanggungjawaban keuangan yang dilakukan oleh manajemen. d. Filosofi dan gaya operasi

Filosofi adalah seperangkat keyakinan dasar yang menjadi parameter bagi perusahaan dan karyawannya. Filosofi mengarahkan tindakan dan sikap manajemen dalam menjalankan aktivitas perusahaan. Sedangkan gaya operasi mencerminkan ide manajer tentang bagaimana operasi suatu entitas harus dilaksanakan. Sesuai dengan hasil tabulasi kuesioner, PT. Bank Perkreditan Rakyat (BPR) Phidectama Biak telah memiliki filosofi dan gaya operasi.

e. Struktur organisasi

Struktur organisasi merupakan suatu kerangka yang menunjang seluruh fungsi yang ada dalam suatu organisasi berikut tugas, wewenang dan tanggungjawabnya dengan jelas. PT. Bank Perkreditan Rakyat (BPR) Phidectama Biak telah memiliki struktur organisasi yang berbentuk fungsional dimana masing-masing bagian memiliki satu fungsi dari berbagai fungsi organisasi.

f. Pembagian wewenang dan tanggung jawab Perluasan dan pengembangan struktur organisasi terlihat dari penetapan wewenang dan tanggung jawab. Dalam suatu organisasi harus ada sistem yang mengatur pembagian wewenang dan tanggung jawab untuk mengotorisasi suatu transaksi. Dalam hal transaksi harus melibatkan lebih dari satu unit organisasi agar terdapat kontrol internal dari masing-masing bagian. Dalam pelaksanaannya PT. Bank Perkreditan Rakyat (BPR) Phidectama Biak telah memiliki batasan yang jelas mengenai tugas, wewenang, dan tanggung jawab dari masing-masing bagian mulai dari manajemen puncak sampai manajemen yang ada dibawahnya. Pembagian wewenang dan tanggung jawab organisasi PT. Bank Perkreditan Rakyat (BPR) Phidectama Biak sudah baik dan jelas, namun masih terdapat perangkapan fungsi yaitu bagian kredit.

g. Kebijakan dan praktek sumber daya manusia Aspek penting dalam sistem pengendalian intern adalah personel organisasi. Pelaksanan pengendalian intern sangat tergantung pada personelnya. Oleh karena itu setiap personel dalam organisasi dituntut memiliki integritas yang tinggi, nilai etika dan pengetahuan serta keterampilan yang diperlukan. Sesuai dengan tabulasi kuesioner yang ada, PT. Bank Perkreditan Rakyat (BPR) Phidectama Biak telah memiliki kebijakan dan praktek sumber daya manusia yang cukup baik. PT. Bank Perkreditan Rakyat (BPR) Phidectama Biak telah memiliki metode yang baik dalam menerima karyawan, pengembangan potensi karyawan, penilaian prestasi karyawan, serta pemberian kompensasi atas prestasi karyawan. Dalam hal pengembangan sumber daya manusia, PT. Bank Perkreditan Rakyat (BPR) Phidectama Biak selalu mengadakan pelatihan-pelatihan sendiri maupun mengikuti pelatihan-pelatihan yang diadakan pihak luar yang sesuai dengan bidang tugasnya. 


\section{Penaksiran risiko}

Penaksiran risiko untuk tujuan laporan keuangan adalah identifikasi, analisis, dan pengelolaan risiko entitas yang berkaitan dengan penyusunan laporan keuangan, sesuai dengan prinsip akuntansi berlaku umum. Penaksiran risiko manajemen merupakan penaksiran risiko tertentu dalam laporan keuangan dan didesain serta implementasi aktivitas pengendalian yang ditunjukkan untuk mengurangi risiko tersebut pada tingkat minimum dengan mempertimbangkan biaya dan manfaat. Unsur penaksiran risiko menggambarkan sistem pengendalian intern pemberian kredit di PT. Bank Perkreditan Rakyat (BPR) Phidectama Biak sudah baik dan memenuhi syarat untuk dikategorikan sebagai penaksiran risiko yang baik menurut ketentuan yang sudah ditetapkan.

\section{Informasi dan komunikasi}

Sistem akuntansi diciptakan untuk mengidentifikasi, merakit, mengolongkan, menganalisis, mencatat, dan melaporkan transaksi-transaksi entitas serta untuk menyelenggarakan pertanggungjawaban kekayaan dan utang tersebut. Komunikasi mencakup penyampaian informasi kepada semua personel yang terlibat dalam pelaporan keuangan tentang bagaimana aktivitas mereka berkaitan dengan pekerjaan orang lain. Unsur informasi dan komunikasi menggambarkan sistem pengendalian intern pemberian kredit. PT. Bank Perkreditan Rakyat (BPR) Phidectama Biak sudah baik dan memenuhi syarat untuk dikategorikan sebagai informasi dan komunikasi yang baik menurut ketentuan yang telah ditetapkan, karena sistem pengendalian intern yang diterapkan sudah mampu memberikan keyakinan yang memadai dengan adanya transaksi yang dicatat atau terjadi adalah sah, telah diotorisasi, dicatat, dinilai secara wajar, telah dicatat dalam periode yang seharusnya, telah dimasukkan ke dalam buku pembantu dan telah diringkas dengan benar. Informasi disampaikan kepada semua personel yang terlibat dalam pelaporan keuangan tentang bagaimana aktivitas yang terkait dengan pekerjaan orang lain, baik yang berada di dalam maupun di luar organisasi, dan informasi tersebut mencakup pedoman kebijakan, pedoman akuntansi, dan pelaporan keuangan.

\section{Aktivitas pengendalian}

Aktivitas pengendalian merupakan kebijakan dan prosedur yang dibuat untuk memberikan keyakinan bahwa petunjuk-petunjuk dari manajemen telah dilaksanakan. Aktivitas pengendalian tersebut meliputi:

a. Pengendalian pengolahan informasi

Pengendalian pengolahan informasi meliputi organisasi pusat pengolahan data, prosedur dan standar untuk perubahan program, pengembangan sistem dan pengoperasian fasilitas pengolahan data. melaksanakan mengenai aktivitas pengendalian aplikasi, PT. Bank Perkreditan Rakyat (BPR) Phidectama Biak telah melaksanakan aktivitas pengendalian aplikasi yaitu setiap transaksi permohonan kredit harus mendapat persetujuan dari pejabat yang berwenang, setiap transaksi pengeluaran kas harus mendapat otorisasi dari pejabat yang berwenang, pencatatan transaksi permohonan kredit mendapat otorisasi dari pejabat yang berwenang, transaksi permohonan kredit dicatat pada saat terjadi atau segera setelah transaksi terjadi, dokumen persetujan kredit dirancang bernomor urut tercetak, dokumen dan catatan dirancang cukup sederhana untuk menjamin kemudahan dalam pemahaman terhadap dokumen dan catatan tersebut serta mendorong pengisian dengan benar, akan tetapi belum ada karyawan yang independen yang bertugas untuk mengontrol piutang yang terjadi atas transaksi pemberian kredit.

b. Pemisahan fungsi yang memadai

Pemisahan fungsi bertujuan agar masing-masing karyawan tidak melakukan tugas yang tidak sesuai dengan wewenang dan tugasnya. Pemisahan fungsi harus dibuat dan dirancang dengan jelas mengenai uraian tugas, wewenang, dan tanggung jawab dengan tujuan untuk mencegah dan mendeteksi adanya kesalahan dan ketidakberesan dalam pelaksanaan tugas. Pelaksanaan transaksi yang terjadi harus dibagi dalam berbagai fungsi sehingga masing-masing fungsi dapat saling mengawasi PT. Bank Perkreditan Rakyat (BPR) Phidectama Biak melaksanakan aktivitas pengendalian untuk pemisahan fungsi yang memadai yaitu telah dilakukan pemisahan fungsi antara fungsi penyimpanan kas dan fungsi akuntansi, fungsi pemberian kredit dengan fungsi penyimpanan kas, fungsi pemberian kredit dan fungsi akuntansi, belum ada pemisahan fungsi antara fungsi pemberian kredit dan fungsi otorisasi kredit.

c. Pengendalian fisik

Pengendalian fisik meliputi penyimpanan dokumendokumen, catatan-catatan serta barang jaminan kedalam almari besi yang atau ruangan yang aman. Untuk penyimpanan dokumen-dokumen penting tersebut diperlukan almari besi yang tahan terhadap api untuk melindungi dokumen-dokumen penting perusahaan. PT. Bank Perkreditan Rakyat (BPR) Phidectama Biak almari besi yang tahan terhadap api untuk menyimpan dokumen perjanjian kredit, serta sudah disediakan tempat untuk menyimpan barang jaminan. Perusahaan juga telah memiliki alat mekanis berupa register kas.

d. Review kinerja

Review kinerja ditujukan untuk menilai sejauh mana keberhasilan pelaksanaan suatu pekerjaan. PT. Bank Perkreditan Rakyat (BPR) Phidectama Biak telah melaksanakan aktivitas pengendalian untuk review kinerja, yaitu manajemen telah melakukan review atas kinerja terhadap laporan-laporan yang meringkas hasil operasional perusahaan, dan manajemen juga telah melakukan review atas kinerja sesungguhnya dibandingkan dengan jumlah anggaran atau hasil-hasil tahun sebelumnya. 


\section{Pemantauan}

Pemantauan merupakan proses penilaian kualitas kinerja pengendalian intern. Aktivitas pemantauan ini dilakukan secara terus menerus pada periode tertentu. Pemantauan harus dilakukan secara teratur dan menyeluruh untuk tiap-tiap bagian yang ada sehingga apabila ada kelemahan dalam sistem pengendalian intern dapat segera diperbaiki tanpa menunggu adanya kesalahan atau kekeliruan. PT. Bank Perkreditan Rakyat (BPR) Phidectama Biak sudah memenuhi syarat untuk dikategorikan sebagai pemantauan yang baik menurut ketentuan yang ditetapkan.

Faktor-faktor yang menghambat implementasi sistem pengendalian intern pemberian kredit pada PT. Bank Perkreditan Rakyat (BPR) Phidectama Biak

Tahap proses pemberian kredit pada PT. BPR Phidectama Biak terdapat hambatan-hambatan yang dilalui. Hambatan tersebut dalam hal proses pemberian persetujuan kredit kepada calon nasabah. Hambatan tersebut dapat diuraikan sebagai berikut:

1. Faktor kedekatan pegawai dengan calon nasabah

Berdasarkan hasil wawancara yang dilakukan bahwa terdapat faktor kedekatan antara pegawai dengan calon nasabah. Faktor kedekatan ini memengaruhi disetujuinya permohonan kredit yang diajukan. Faktor kedekatan ini memengaruhi disetujuinya permohonan kredit yang diajukan, kedekatan yang dimaksud disini adalah apabila adanya faktor keluarga yang bekerja di PT. BPR Phidectama Biak atau memiliki hubungan baik dengan pegawai PT. BPR Phidectama Biak, sehingga permohonan kredit akan mudah untuk disetujui oleh pihak bank, tetapi faktor kedekatan ini tidak memengaruhi mengenai persyaratan yang harus dilengkapi. Faktor dekat atau tidak dengan pegawai syarat-syarat pengajuan kredit tetap harus dilengkapi sesuai prosedur yang telah ditetapkan.

2. Persyaratan tidak lengkap dalam pengajuan permohonan kredit. Permohonan kredi pada PT. BPR Phidectama Biak, apabila persyaratan tidak lengkap disebabkan karena calon nasabah yang tidak teliti dalam membaca persyaratan yang diperlukan. Persyaratan yang kurang ini, nantinya akan menunda proses permohonan kredit sampai persyaratan yang disyaratkan dipenuhi. Contoh konkret yang biasa terjadi di PT. BPR Phidectama Biak adalah untuk yang kredit umum atau UMKM mereka terkendala dengan tidak adanya atau belum membayar pajak tanah dan pajak sepeda motor yang belum dilunasi pembayarannya, sehingga nasabah harus mengurusnya terlebih dahulu.

3. Informasi palsu yang diberikan oleh calon nasabah Informasi palsu banyak diberikan oleh calon nasabah agar permohonan kredit diloloskan. Informasi yang tidak sesuai ini nantinya juga akan menghambat proses selanjutnya dalam prosedur pemberian kredit. Informasi kredit ini biasanya akan terlihat pada saat kunjungan yang dilakukan oleh pihak bank. Contoh konkret yang sering terjadi di PT. BPR Phidectama Biak yaitu jaminan pada sertifikat tanah tidak sesuai dengan syarat, misalnya tempat usaha yang di tengah sawah, tidak memiliki akses jalan, dan di dekat tepi sungai. Tanah sawah seringkali banyak yang tidak ada jalan akses masuk. Nasabah terdapat ada yang menipu diri sendiri seolah-olah dia mampu akan tetapi sebenarnya tidak mampu.

\section{Kesimpulan}

Berdasarkan hasil analisis data dan pembahasan terhadap implementasi sistem pengendalian intern dan prosedur pemberian kredit pada PT. Bank Perkreditan Rakyat (BPR) Phidectama Biak, maka dapat disimpulkan sebagai berikut :

1. Prosedur pemberian kredit di PT. Bank Perkreditan Rakyat (BPR) Phidectama Biak sudah sesuai dengan ketentuan prosedur yang dimiliki, walaupun dalam prakteknya masih terdapat penyimpanganpenyimpangan yang dilakukan. Prosedur pemberian kredit di PT. Bank Perkreditan Rakyat (BPR) Phidectama Biak antara lain : permohonan kredit, analisis peninjauan nasabah, analisis laporan hasil peninjauan nasabah, keputusan kredit, persetujuan permohonan kredit dan pencairan kredit.

2. Implementasi sistem pengendalian intern pemberian kredit pada PT. Bank Perkreditan Rakyat (BPR) Phidectama Biak sebagian besar dalam komponen lingkungan pengendalian, penilaian risiko, informasi dan komunikasi, pemantauan sudah sesuai dengan komponen pengendalian intern menurut COSO.

3. Faktor-faktor yang menghambat implementasi sistem pengendalian intern pemberian kredit pada PT. Bank Perkreditan Rakyat (BPR) Phidectama Biak antara lain : faktor kedekatan pegawai dengan calon nasabah, Persyaratan tidak lengkap dalam pengajuan permohonan kredit, dan informasi palsu yang diberikan oleh calon nasabah.

\section{DAFTAR PUSTAKA}

Abdullah, T. dan Tantri. 2012. Bank dan Lembaga Keuangan. Jakarta: PT Raja Grafindo Persada.

Ayu Dwi Purwatiasih, Anantawikrama Tungga Atmadja, Nyoman Trisna Herawati, (2014), dengan judul penelitian Analisis Pengendalian Internal Dalam Pemberian Kredit pada PT. BPR. Kanaya.

Budisantoso, T. (2013). Bank dan Lembaga Keuangan Lain Edisi 3. Yogyakarta: Salemba Empat.

Darmawi, H. (2012). Manajemen Perbankan. Jakarta: Remaja Rosdakarya.

Destiana Restu Prastiwi, (2017), dengan judul penelitian Analisis Pengendalian Intern Sistem Pemberian Kredit Berbasis Coso (Studi kasus di BPR Chandra Muktiartha).

I Putu Mulyadi Saputra, Anjuman Zukhri, Luh Indrayani, (2014), dengan judul penelitian Sistem Pengendalian Intern Pemberian Kredit Pada PT. BPR Suryajaya Kubutambahan.

Kasmir. (2014). Bank dan Lembaga Keuangan Lainnya. Jakarta: PT Rajagrafindo Persada. 
Kuncoro,Mudrajat,

Suhardjono.2002.ManajemenPerbankan Teori danAplikasi. Edisi Pertama. Yogyakarta: BPFE

M.Noor, H. C. (2013). Manajemen Kredit Bank Umum dan Bank Perkreditan Rakyat. Bandung: Quantum Expert.

Muhammad Hanas Adi Putra, Sri Mangesti Rahayu, Muhammad Saifi, (2016), dengan judul penelitian Analisis Pengendalian Intern Terhadap Sistem Pemberian Kredit Modal Kerja (Studi Kasus pada PT. Bank Perkreditan Rakyat UMKM Jawa Timur Cabang Pacitan).

Muljono, T. P. (2007). Manajemen Perkreditan Bagi Bank Komersil. Yogyakarta: BPFE Yogyakarta.

Mulyadi. 2001. Sistem Akuntansi. (ed.3).Jakarta: Salemba Empat.

Mulyadi. 2002. Auditing. Edisi Keenam. Jakarta: Salemba Empat.

Mulyadi. 2008. Sistem Akuntansi. Edisi Ketiga. Jakarta: Salemba Empat.

Neka Ayang Sesiady, Moch. Dzulkirom AR, Muhammad Saifi, (2018), dengan judul penelitian Analisis Sistem Dan Prosedur Pemberian Kredit Modal Kerja Dalam Upaya Menudukung Pengendalian Intern (Studi Pada PT. BPR Nusamba Wlingi Cabang Kepanjen).

Romney, Marshall B, dan Paul John Steinbart. 2006. Accounting Information System. Edisi Sembilan. Jakarta: Salemba Empat

Setyawati, Agatha Gerry. 2007. Analisis Pengendalian Intern Pada Sistem Pemberian Kredit (Studi Kasus pada PT. BPR Karticentra Artha). Skripsi Ekonomi. Program Sarjana. Universitas Sanata Dharma

Simorangkir, U., dkk. 2000. Kredit Perbankan di Indonesia. Yogyakarta: Andi Offset

Suyatno, Thomas. 1995. Dasar-Dasar Perkreditan. Jakarta: Gramedia Pustaka Utama

Suyatno, Thomas. 2007. Dasar-Dasar Perkreditan. Jakarta: Gramedia Pustaka Utama

Undang-Undang RI Nomor 10 Tahun 1998. Manajemen Perbankan. Jakarta: Penerbit Ghalia Indonesia.

Yenni Vera Fibriyanti, Oktavia Ikke Wijaya, (2018), dengan judul penelitian Analisis Sistem Pengendalian Internal Pemberian Kredit pada PD. BPR Bank Daerah Lamongan.

Zaharman. (2017). Analisis Pengendalian Intern Pemberian Kredit Pada PT BPR Mitra Rakyat Riau. Jurnal Ilmu Akuntansi dan Bisnis. Vol. 8 No.1: Hal. 1917-1933. 